\title{
WELFARE STATE REFORMS AND QUESTION OF ITS EXISTENCE
}

\author{
LETUNIC, S.
}

Abstract: This paper deals with theoretical evaluations of attempts to reform a welfare state in a view of the neoclassical idea of the market as the only economic regulator. Recent welfare state reforms are most clearly described in A. Giddens' Third way, and have been the basis of some recent socialdemocrat governments proclamations. Neoliberalism uses classic ideas of market conditions and laissez-fair, having, in the conditions of globalisation, an important effect especialy on developing (transition) economies. In these countries, growing factors, such as educated workforce, economic oppenness, internal balance, a decrease in the public consumption share, and importation and adaptation of technology, play a decisive role in the selection of an economic policy or development strategy. Finaly, paper theoreticaly evaluates models of development (neoliberal's and third way's).

Key words: welfare state, third way, neoliberalism, globalization, labour productivity
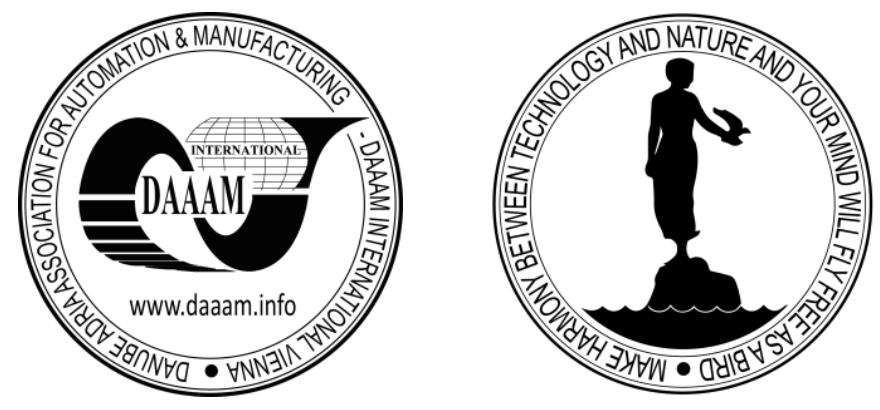

Authors' data: Dr. Sc. Letunic S[tijepo] , University of Dubrovnik, Department of Economics and Business Economics. Lapadska obala 7, 20000 Dubrovnik, Croatia, stijepo.letunic@du.t-com.hr

This Publication has to be referred as: Letunic, S[tijepo] (2015). Welfare State Reforms and Question of its Existence, Chapter 04 in DAAAM International Scientific Book 2015, pp.039-050, B. Katalinic (Ed.), Published by DAAAM International, ISBN 978-3-902734-05-1, ISSN 1726-9687, Vienna, Austria

DOI: $10.2507 /$ daaam.scibook.2015.04 


\section{Introduction}

Welfare state now generates almost as many problems as it resolves. The basic assumption is that these difficulties are caused by the fact that the maintenance of the achieved level of social rights and social protection contradicts the short-term economic indicators of growth and efficiency. Keynesian assumptions were at the time when majority threatened by the unemployment were laborers, and Keynesianism supposed superiority of the domestic economy over foreign trade of goods and services. Welfare state, according to neoliberalism, is the cause of moral collapse and the so-called new individualism in a negative context, with the idea of individual "me first", what should be disastrous for social solidarity (Giddens, 2013). Unlike the neoliberals(libertarians) third way is not for its abolition, but for its reconstruction. In addition to education, which third way particularly points out, as the value and possibility essential is involvement in the work process as well as job prospects. One of the goals of the welfare state is a bourgeois culture in terms of the changes caused by globalization. Global deregulated market also creates new relationships between states and nations.

Traditional system of the welfare state is considered Bismarck's welfare system in Germany. For that system as well as in Austria and Belgium characteristic is that nonprofit groups provide about half of social services (Giddens, 2013). However, different countries have been developing different systems of the welfare state, Scandinavian, Bismarckian, Southern European, Anglo-Saxon, Eastern European, and East Asian (Kima et al, 2012). For example, United Kingdom gave priority to different social services and assistance, Scandinavian countries due to the high taxes secured high benefits from the funds of social welfare, while Central European countries have given attention to privileges on the basis of employment, i.e. contributions to social security. The countries of northern Europe are often taken as an example of a successful welfare state. One can argue that the position of individual countries in international trade influenced the kind of social system individual country chooses. So generous social systems should have arisen from economies with a high employment rate and large investments. So in this view, decisive is not only a choice of policy options, but also place of individual economy in the world economic relations.

Hayek with compatriot Mises are important theorists of neoliberalism, whose theory is characterized by the liberal faith in laissez-faire free market as a precondition for individual freedom from totalitarian tendency itself and its bureaucracy. In addition to the "libertarian" reasons, for neoliberals is most important Hayek's faith in the free market, in terms of its effectiveness against any intervention in the economy (but even the most critical of intervention Hayek, did not abandon it because of its ineffectiveness but the threat to freedom). The critique of interventionism in economic policy is that it is too similar to the methods of the natural sciences, or positivist methods. The outcome is considered to be largely unpredictable, and often artificial. Hayek points out excessive trust in science in general, which leads to a tendency of solving economic problems that way, while neglecting the importance of individuals who are engaged in their partial areas of the market. Such unorganized knowledge 
which does not fall under the scientific knowledge he calls the knowledge of the particular circumstances of time and place (Hayek, F.A. \& Mises, L.v., 1998).

In all of this the question of the meaning of the welfare state is being raised, which is a „burden“ to many economies, and especially to economies in transition.

\section{Third way welfare state reforms}

Social welfare state, which emerged from the state engineering and realization of social rights without back responsibilities, has come under criticism from neoliberalism. On the other hand, already came to definitive collapse of the former planned economies in Eastern Europe, i.e. later transition countries. In response appeared "third way" (attempt in a sense that social democracy had to overcome old school and neoliberalism) which in compliance with the specifics of individual countries accepted almost all of the European social democracy. At that main motto of the third's way new approach is "no rights without responsibilities" and this applies not only to the users of welfare, but also to others.

Failure of companies and changes in market are characteristics of dynamic market. In this sense, for the transitional period, for third way required is certain material and moral support to individuals from the government. Also, third way does not consider huge inequalities as a major source of economic progress (Thorbecke, E. \& Charumildin, C., 2002), but their presence would be affected primarily with the "redistribution of opportunity" as opposed to the redistribution "post factum". The welfare state is focused on the individual, not the family, and has a solidarity effect in a positive context. The goal is a job that implies education. Social cohesion cannot be guaranteed by government action from above or by tradition (Giddens, 2013).

There is also the question of whether there are, in general, any more the differences between left and right. The fact remains that the left advocates for greater equality, while the right is looking at society as hierarchical (Bobbio, 2006). Equality is important to the life chances of people, well-being and self-esteem.

Of third way values Giddens states equality, protection of the weak, freedom as autonomy, rights with responsibility, authority with democracy, cosmopolitan pluralism, philosophical conservatism (certain reticence towards progress and nuanced understanding of science and technology with regard to the consequences). Giddens' third way program proposal includes: Radical Center; The new democratic state (state without enemies); Active civil society; Democratic family; The new mixed economy; Equality as inclusion; Positive welfare; State social investment; Cosmopolitan nation; Cosmopolitan democracy.

The concept of sustainable development cannot be precisely determined, and there is at least forty of its definitions and is therefore more guideline for action but not the exact formula. The risk that today's technological development carries with it should be "energizing" for the society, not just a negative factor. Third way, in contrast to classical social democracy, emphasizes the role of markets and competition more. In all this it stands for an important role of the state in investing in human resources, infrastructure and entrepreneur culture. Third way in relation to the classical social 
democracy stands for a new mixed economy where there is a synergy between public and private, where in addition to market discipline there is awareness for the public interest. Neoliberal model sees only equality in equality of opportunity, so-called meritocracy. In this case there would exist excluded class of dissatisfied individuals who would regard the reason for their failure as a result of their lack of ability. It's like in Spencer's neodarwinism (Walters, 2002). Also there would be a big downward mobility with all of its social consequences. In contrast to this position, third way defines equality as inclusion and inequality as exclusion. The main context of possibilities is access to work, of which depends economic status of the individual, but also self-esteem. Besides work, education is another condition. Inclusion and exclusion in society are greatly influenced by changes in the composition of the workforce, because today, in developed economies, less than fifth of the workforce is employed in the industry.

Giddens as inclusive society considers: Equality as inclusion; Limited meritocracy; Renewal of public space(civil liberalism); «Beyond the work society»; Positive welfare; The social investment state. State welfare system should not turn solely in helping most vulnerable, but also to raising the quality of public space, quality health services, crime fighting for the use of most, and according to Gidenns, helping creation of common civil morality. Third way accepts neoliberal critique of the welfare state in a sense it is undemocratic, because the benefits are distributed from the top down, and that does not leave enough space to personal freedom. For creation of new jobs, as the main source of economic power, crucial is investment in the human resources, than supporting entrepreneurial initiatives and sometimes helping the government to create capital. In addition to supporting life-long learning, because of the increasingly changing workplace, it is important to affect the cognitive and emotional abilities of individuals. It is important to try to reconcile employment and family, for example, in a way of working at home on the computer or on unpaid leave. In the western economies the share of jobs with full-time as well as long-term ones decreases, and it is necessary to consider a redistribution of work. It is often the case that with shorter hours labor productivity significantly increases.

Government interference in matters of social economy, in the light of the basic aspirations of third way makes sense regarding the revival of civil culture. The main focus in the society of positive welfare are becoming autonomy and development of people (Giddens, 2013). Global deregulated market creates new relationships between states and nations. Important is a change in comparison to old nationalism, by creating a cosmopolitan nationalism where love for country is associated with the acceptance of others and the rights of the individual. Borders do not have the role as before, and states lose part of their sovereignty. Cosmopolitan nationalism in terms of global order implies a cosmopolitan democracy on a global scale that is still missing. At the global level, it is necessary to consider the issue of regulation of market fundamentalism, which can not remain unregulated because all individual economies are regulated. Often is said that in a process of development of world economy, global laissez-faire is not its last point, but is only temporal. 


\section{Neoliberalism}

After theoretical Hayek neoliberalism through pragmatic development took its present form. But one is scientific and the other ideological conviction that, building on the classical and neoclassical economics, characterizes neoliberalism. Neoclassics and (neo)liberals can be seen as synonymous, with the first in a greater extent relying on economic science and the second on ideology. In the meantime, neoliberalism had its expression in reagonomics, thatcherism and monetarism led by Friedman.

Neoliberals believe that only kind of equality in society is the so-called equality of opportunities out of what stems meritocracy (,you get what you deserve“) (Arrow et al, 2000). Neoliberals believe at the formal equality of participants in a liberal society, but at the same time the majority believes in the inequality of participant's talent (http://mondediplo.com/1998/12/08bourdieu, accessed 02.04.2014.). Although there is a declared equality of opportunities in society, the fact is that the access to education, as a rule, have children of wealthy parents what leads to the practice that education of the parents conditions the education of children. It can be said that modern education system transmitting inequality over time creates a stable elite in a similar way as the aristocratic system before.

Market liberalism has a special faith in the market, which is separated from the real production of goods and services. This way market becomes self-contained, and it is one of the reasons to talk about neoliberalism, not liberalism. In addition to the faith in the market, crucial is the faith in entrepreneurs and entrepreneurship. As the market, also civil order, if left to itself, will bring the greatest good to society. Pervasive is the idea that the market should be comprehensive, including all of society. Thus, all individuals would be involved in the market and it would be their measure. This also means that their social life would be defined by the market. This is followed by example of neoliberal ideas such as that an individual should be an entrepreneur for himself managing his life in that way. Thus, an individual chooses his friends, and other activities in a way by which he would later have more success in employment. This attitude was not typical of early liberalism.

The general tendency of neoliberalism is to intensify and expand markets by increasing the number of transactions, or increase their incidence. Market expanding is reflected in the new forms of competition in space and time, such as the 24 - hour shop working hours, time controls of the departure of employees to toilet, reducement of the duration of employment contract which force the employee to do it more often, etc. Creation of new type of transactions has no limits except in the growth of computer capacity. For example, in the securities sale, to the existing options are added new options. This increases the transaction cost that grows regardless of the amount of production. For neoliberalism typical are also creations of sub-markets as well as within the company where parts of the organization or even individuals compete as rival companies. All this implies the destruction of the welfare state(social state) and the creation of wealth through market-driven economic growth.

In the new global conditions neoliberals observe the world as a market metaphor, nations as a companies, as well as individual regions which compete side by side. This view of the state as a competitive enterprise can be called neo-nationalism, not only 
neoliberalism. Despite this global orientation, neoliberals as defenders of the traditional nation have realist theory of international relations and the global system is still composed of nation-states, and important power is still manifested in maintaining of military force (http://web.inter.nl.net/users/Paul.Treanor/neoliberalism.html, accessed 02.04.2014.).

It is worth reminding that in regard to regions, countries, as well as global market, complete mobility of capital and labor, which is a requirement of efficiency and competition, for most economic sectors is an illusion. The views of economists about the success of neoliberal policies in global terms differ (see more World Bank, 2002; Wade, 2004; Dollar \& Cray, 2001; Dollar \& Cray, 2002). Japanese author Kenichi Ohmae has much more positive view of the role and correlation of regions in the global economy. He says it's a lie to look at the national territory as a single economic unit. The neo-liberal critique of nation states is that they are political organisms and that their "bloodstream cholesterol builds unstoppably". „Cholesterol growth" in the states may occur due to the special interests, state support (subsidies), protection and social minimum for the public (civil minimum), such as in the social programs of Scandinavian economies, "social contracts" of German Trade Unions, the Swiss economy full of cartels, the agricultural lobby in France, lobbies of construction industry and rice producers in Japan or the defense industry in the United States (Ohmae, 2008). It is very difficult for this process to be reversed.

As an important argument in the reduction of the welfare state pointed out is the inefficiency of state structures. Highlighted is the ease with which inefficient manager can spend entrusted money, and the fact that the same product can be achieved with large differences in costs. Besides that, size of bureaucratic structure creates loyal electorate which governments seek to pander in order to remain on power. Also, inefficient expert will always strive for bureaucratic power because in competitive conditions he cannot succeed. A similar theory is that an individual who cannot withstand the competition will look back on it as some kind of "mad competitive system".

Interventionism of the welfare state, according to neoliberals, produces two conflicting classes - class of recipients of compensation and much more numerous class of those who pay compensation. The government can give to one group only what it takes away from the second. Also in terms of government intervention, the government has access to countless measures which can harm exports and thus free trade and the efficient allocation of capital. Neoliberals highlight the confidence in the price system as well as the forwarding of information in a sense that individual limited horizons of all participants sufficiently overlap, and through many intermediaries the relevant information is forwarded to all. They also point out the role of incentives which motivate individuals to do the desirable things without anyone telling them what to do. At neoliberals criticized is also confidence in the scientific methods consisting in the application of finished techniques, what makes to seem that social problems can be solved as by using a cooking recipe. So sometimes it seems that it is easier to master scientific technique than to notice the problem and properly deal with it. The outcome measure is considered largely unpredictable and often as artificial intervention. It is believed that the such (interventionist) measures can only lead to more general 
prediction while including only a fraction of the necessary variables in numerical predictions (Hayek, F.A. \& Mises, L.v., 1998). Thus, Hayek says that he appreciates more „true“, although imperfect knowledge, even though it leaves lot of uncertainty and unpredictability, but the semblance of exact knowledge that is likely very wrong.

In the neoliberal ideology crucial is a relationship to the environmental problem (as part of the third generation of human rights the major part constitute environmental rights, Bazdan, 2008) where the idea of a solution of environmental problems left to the market, is one of most fragile. So neoliberals consider environmental problems exaggerated (misuse of science) and the consequence of misleading the public. According to the neoliberal theory replacing spontaneous processes with "conscious human control" is by no means acceptable (Hayek, F.A. \& Mises, L.v., 1998). The idea of "the common good" is reflected in the fulfillment of collectivist interests, which is according to neo-liberals empirically manifested in a bad way. Also criticized is the collectivist spirit that despises "selfish interests" of the individual and who, on behalf of the objectives of the community, considers his attitude as superior. So, besides criticism of confidence in science in solving economic problems through government intervention, there is also critical view on management structures as being bad. One of the reasons neoliberalism is in trouble - is that market fundamentalism and conservatism - are in mutual tension.

\section{Theoretical economic evaluation of models}

The main characteristic of the neoliberal model of development, as already mentioned, is reflected in the attitude of neoliberals towards the role of government in a market economy. Economic intervention or regulation of the market in order to achieve economic goals means any economic measure at costs, prices or exchange rates formed at the level where they would not otherwise be set with free operation of the market (Pertot, 1980). Neoliberal idea excludes the idea that government intervention can do something positive for society, even in the long run. In doing so, emphasized is the state deficiency at having particular market information as individual in the market has. It also takes position (argues) that private ownership is significantly more efficient than state's. But the efficiency of the company depends on the management, not on the kind of ownership. Well (or badly) can be managed both public and private enterprise, in the same way as one can drive private or public car, well or badly. In modern corporations management is separated from the ownership. Among the limiting factors of the market functioning neoliberals include trade unions. Their thesis is that with wage ,non-rigidity“ for unemployed it is much easier to find a job. However it should be noted that not only the unions are the cause of wage rigidities, ie. more difficult wage reducement, but according to the Keynes it is inherent to market system. It is also logical that larger pressure of unemployed in job search, is focused on the market. Reliance on state would facilitate wages rigidity.

Neoliberals emphasize the market as a miracle that registers all of the information changes, fluctuations and responds to them. This interdependence of individuals and the freedom of action and competition, at the same time regulates the power of the individual and realizes his "freedom" (Friedman, 2002). It is necessary to distinguish 
between the theoretical position and attitude of neoconservatives who favor a smaller state role in market competition, at the same time strictly opposing the removal of interstate barriers if it is not in their interest. It can be concluded that the ideas of liberalism often present individuals by whom they are not theoretically adopted at all, but they use them as needed (Anagnoste et al, 2009). We should not forget that the neoliberal emphasis on markets is not connected with what is happening on the competitive market. Neoliberals rise up free market on a pedestal formally supporting neoliberal positions, however, they will benefit on the basis of market imperfections established by institutions, such as, for example, preferential taxation, subsidies and so on. This applies, for example, to energy, agriculture and production for military purposes, as well as the corruption that is, for example, in the United States called lobbying. It is certain hypocrisy. Thus most of proclamations such as "we believe in free market" are sheer demagogy. Neoliberals believe in the market but in such a market they do not participate because of their monopolistic, oligopolistic, or power in monopolistic competition. So small companies operate in a competitive environment, but TNCs (or MNCs) or similar do not.

In economic terms, partly against the neoliberal theory is the fact that the market is not perfect, if it means anything at all. It is worth mentioning classic objections to neoliberal model of development concerning the existence of market's defects such as imperfect information, natural monopolies, externalities in production and consumption, the lack of complete markets, microeconomic decisions that may be rational while they in macro aggregates become harmful, then market adapting which is not momental, income distribution which is random, production and consumption set that are not convex, the inability of marginal equations since all products are not divisible etc. (Horvat, 2002).

The question is whether, since we are part of the material world and dependent of material(negative), a market that valorizes our actions can evaluate also very shortsighted and self-destructive phenomena that result from the mass consciousness with the mass interaction. Man is a social being and its fulfillment is not exhausted through the satisfaction of material existence, which is the ideal of neoliberalism. The main man's purpose, among others, is not satisfaction of man's material existence but intellectual maturation through which one understands nature and himself. Intellectual maturation is the task of each individual in its promotion. Thus sacrifice within the free market in the sense of redistribution should be accepted by those from whom is taken, or by those who lose, all for the purpose of the higher good.

One of the arguments of neoliberalism is that man accepted the idea of science as a superior to regular market activity of the individual and that way he interferes with the "miraculous" effects of the market. Supporters of neoliberalism call this endless confidence in science, which is elevated above the limited views of market participants. At the same time, in interaction of so many market participants, they point out the impossibility of knowledge of market trends. According to neoliberals their critics believe that the market is stupid and that there is a want to control progress. One could say that the market is not stupid, but is composed of a set of individual interests, who cannot see further than their own backyard. The evolution of social institutions symbolized in the idea of individual rights and democracy is considered a product of 
spontaneous interaction in society, and therefore the utilitarian product, unlike the position that claims it is exclusively the product of learning and science. The question is "why should we not know how something needs to be and how something is?"

The neoliberal idea is that social solidarity and subsequent social transfer should not be made by the state, but in the community, usually through the traditional way of help. The society would be completely left to the market, but individuals would, if necessary, help each other. It also means that the moral code at that matter would differ between different communities and that state could not affect it. As stated exactly this is critique of neo-liberalism which on one side relies purely on market, and on the other calls to traditional values. This means abandonment of values that can be crucial to society to certain disorganization. These values in any case are hard to determine, but historically the greatest impact on them had a civil or religious authority.

One of the areas that in the short term as well as the long term has a significant impact (Velosoa, L. \& Estevinha, S., 2013) on economic growth is education. Education left to the market would be available mostly to the rich, who would remain educated and then create elite. Noble idea of accessibility of education to all strata of society is deprived in neoliberalism. It is similar with the health care. For example, the neoliberal approach in the USA implies knowledge (because centres of knowledge are there), while in economies in transition, it is not included. Knowledge does not originate only from the amount of material investment in it, but also from its evaluation in education and society, and thus releasing the creative force for the future. In transition economies further issue is in the effort that native population (Druzic,I. \& Sirotkovic, J., 2002) has a share of the surplus value (if not present, then future) that is created, either through securities or property of the state (Druzic, G., 2002).

Important human achievements of the past in the field of science and art were achieved thanks to the economic independence, what often included support of state and government. It should be noted that many of these achievements had not been for the purpose of profit and "profitability". Thus, these and other benefits would primarily depend on the merits of individuals in the market, or the merits of their predecessors. These merits should relate only to the earnings in the market, what means that only commercially successful products would be valuable. Neoliberal discourse argues that market should be comprehensive, involving all sectors of human activity, including those which are of public interest, such as the preservation of the environment, which is a prerequisite for a "normal" existence. Yet it is very difficult to suppose that something like this is implemented voluntarily and not under the pressure of legislation. Manufacturers would rather invest in the competitiveness of their products, but in innovative ways of production (something that will prevent adverse outcomes). This prevention is not even that important, but a new approach to nature and ecology. Even more problematic is the argument of redistribution and social benefits. Characteristical is neoliberal's opinion in a sense why what is earned through higher taxes has to be allocated to the state, thus reducing potential investment and potential earnings. What is present in this attitude? Selfishness, which for centuries was necessary for mere survival, as it is today. Perhaps few percents less tax inhibit someone's existence, and the state takes it from them. Or that few percents allows 
already large capital better chance of development. Excluding maybe state investment in the necessary infrastructure, government spending for socially vulnerable according to neoliberals is throwing their money away, besides reducing the efficiency of the factors that affect economy.

The key question is whether pressure or necessity provide highest productivity of the individual or there is something else? Do they "draw" most from individual, regardless of what that it limits his freedom and natural creativity? According to the neoliberals employed themselves would function much better if there was not so much social support as well as trade unions, which reduce the competitiveness of employees and lull them in their relative safety? The neoliberal argument therefore is that the survival and relative exclusion of individuals from the community are necessary and useful for the productivity of the economy. That thought believes that greater pressure on something brings best results. Similarly, relationship between nations is viewed through militant aspect where domination changes according to the size of the military force. Similar is view of nations in dependence of power that springs from their market dominance. It follows that, as our purpose, the function of individuals would be competition and survival of the "fittest". If such a concept is applied in the economy then any intervention harms our competitiveness. In fact by following emulation of their interests in earning and power of individuals in the market, society would be most successful and would depend on the unfettered satisfaction of such interests. Famous physicist says: "Even if life is only a relationship of powers, I would not want to live in such a world (Einstein, 2005)".

It is incontestable that the competitiveness and competition is necessary. Taking as an explanation of the socio-economic reality only competitiveness and competition, and therefore the success in the market, we forget that it arises out of something, that is, that it has its cause. So this explanation would be that the power is because of power. The power can result from, for example, solidarity (altruism). It is possible that this is the power that brings success in the market!? However argument of highly-stressed working conditions and maximum competitiveness, such as in physics, cannot be applied to the labour force, because that would mean human being has the same purpose, as for example stone or meteorological changes which work by definable rules. At that, requirements of survival and adaptation would be imposed by the market. By this thinking present is the will to ascend particularity to the rank of principle though causality exists independently. Since the question of causality is more complex we cannot leave it only to the market, whose only purpose is the use of material goods, and not understanding the question of causality, therefore the state is necessary here. Another question is whether the state is doing its job in the right way. That depends on the quality of its structure and personnel. Hayek denies that state structures due to the relative inexactness and indeterminacy of phenomena can deal with the issue of causation. This attitude at the same time denies possibility of constructive reasoning from the perspective of macro-whole. However, from the perspective of economic science, some phenomena can be generalized, even if not one hundred percent accurately, but still sufficiently accurately to be relevant. Nevertheless, in state 
intervention one should be very cautious. For example, issues such as investment in education and social investment also require understanding of the relative importance of these areas on the macro-whole level, but are of long-term and strategic importance.

\section{Conclusion}

Welfare state now generates almost as many problems as it resolves. Nowadays, the welfare state is completely disempowered since new centers of actual, economic power are not anchored in it. Social welfare state, which emerged from the state engineering and realization of social rights without back responsibilities, has come under criticism from neoliberalism. In response appeared "third way"(attempt in a sense that social democracy had to overcome old school and neoliberalism). Hayek says that he appreciates more "true“, although imperfect knowledge, even though it leaves lot of uncertainty and unpredictability, but the semblance of exact knowledge that is likely very wrong. The third way, in contrast to classical social democracy, emphasizes the role of markets and competition more. In all this it stands for an important role of the state in investing in human resources, infrastructure and entrepreneur culture. Third way in relation to the classical social democracy stands for a new mixed economy where there is a synergy between public and private, where in addition to market discipline there is awareness for the public interest. One of the reasons neoliberalism is in trouble - is that market fundamentalism and conservatism - are in mutual tension. Neoliberals emphasize the market as a miracle that registers all of the information changes, fluctuations and responds to them. This interdependence of individuals and the freedom of action and competition, at the same time regulates the power of the individual and realizes his "freedom". The neoliberal idea is that social solidarity and subsequent social transfer should not be made by the state, but in the community, usually through the traditional way of help. This is critique of neoliberalism which on one side relies purely on market, and on the other calls to traditional values. This means abandonment of values that can be crucial to society to certain disorganization. However argument of highly-stressed working conditions and maximum competitiveness, such as in physics, cannot be applied to the labour force, because that would mean that human being has the same purpose, as for example stone or meteorological changes that work by definable rules. Since the question of causality is more complex we cannot leave it only to the market, whose only purpose is the use of material goods, and not understanding the question of causality, therefore the state is necessary here.

\section{References}

Anagnoste, S., Agoston, S., Draghici, M.(2009). Somalia: how to manage an economy outside the system, Proceedings of the 20th International DAAAM Symposium, Katalinic, B.(Ed), 1009-1010, ISBN 978-3-901509-70-4, Vienna, (11)2009, Published by DAAAM International, Vienna 
Arrow, K., Bowles, S., Durlauf, S., N.(2000). Meritocracy and Economic Inequality, Princeton University Press, ISBN 978-0691004686, New Jersey

Bourdieu, P.(1998). The essence of neoliberalism, Available from: http://mondediplo.com/1998/12/08bourdieu, Accessed: 02.04.2014.

Bazdan, Z.(2008). Democracy and Human Rights- Heart of International Economy and Politics, University of Dubrovnik, ISBN 978-953-7153-17-5, Dubrovnik

Bobbio, N.(2006). Liberalism and Democracy, Verso, ISBN 978-1844670628, London Dollar, D., Kraay, A.(2001). Trade, Growth, and Poverty, Finance and development, a quarterly magazine of IMF, Vol.38, No.3, ISSN 0015-1947

Dollar, D., Kraay, A.(2002), Spreading the Wealth, Available from: www.foreignaffairs.org/20020101faessay6561,2002., Accessed: 03.04.2014.

Druzic, G.(2002). Do we need foreign capital, Ekonomija, Vol.9, No.4, ISSN 13300636

Druzic, I., Sirotkovic, J.(2002). Introduction into economy of Croatia, Politicka kultura, ISBN 978-953-258-054-9, Zagreb

Einstein, A.(2005). Mein Weltbild, Ullstein Verlag, ISBN 978-3548367286, Berlin Friedman, M.(2002). Capitalism and freedom, University Of Chicago Press, ISBN 978-0226264219, Chicago

Giddens A.(2013). The Third Way: The Renewal of Social Democracy, Polity, ISBN 9780745666600, Stafford BC

Hayek, F. A., Mises, L.v., (1998). About Free Market, Mate, ISBN 978-953-246-0629, Zagreb

Horvat, B. (2002). Market's defects, Ekonomija, Vol.9, No.4, ISSN 1330-0636

Kima, I.H., Muntanera, C., Shahidie, F., Vivesd, A., Vanroelend, C., Benachd, J.(2012). Welfare states, flexible employment, and health: A critical review, Health Policy, Vol.104, No.2, ISSN 0168-8510

Ohmae, K.(2008). The End of the Nation State: The Rise of Regional Economies, HarperCollins, ISBN 978-0007292271, New York

Pertot, V.(1980). Theory of disparity of costs, prices and currencies, Skolska knjiga, ISBN 978-953-0-61352-2, Zagreb

Thorbecke, E., Charumildin, C. (2002). Economic Inequality and Its Socioeconomic Impact, World Development, Vol.30, No.9, ISSN 0305-750X

Treanor, P.(2005). Neoliberalism: origins, theory, definition, Available from:

http://web.inter.nl.net/users/Paul.Treanor/neoliberalism.html, Accessed: 02.04.2014.

Velosoa, L., Estevinha, S.(2013). Differentiation versus Homogenisation of Education

Systems in Europe: Political aims and welfare regimes, International Journal of Educational Research, Vol.62, ISSN 0883-0355

Wade, R., H.(2004). Is Globalization Reducing Poverty and Inequality?, World Development, Vol.32, No.4, 567-589, ISSN 0305-750X

Walters J.S.(2002). The Ideological Development of US Government Publication 1820-1920, Journal of Government Information, Vol.29, No.1, ISSN 1352-0237

World Bank (2002). Globalization, Growth, and Poverty: Building an Inclusive World Economy, Oxford University Press, ISBN 0-8213-5048-X, New York 